Journal of Social Sciences (COES\&RJ-JSS)

ISSN (E): 2305-9249 ISSN (P): 2305-9494

Publisher: Centre of Excellence for Scientific \& Research Journalism, COES\&RJ LLC

Online Publication Date: $1^{\text {st }}$ October 2016

Online Issue: Volume 5, Number 4, October 2016

http://centreofexcellence.net/J/JSS/JSS\%20Mainpage.htm

\title{
Strategies to enhance early childhood education institution selling point
}

\author{
Sri Wahyuni \\ Faculty of Education \\ State University of Malang
}

\begin{abstract}
This research was aimed at developing substantve theory about strategies to enhance the selling point of early chilhood education institution. This was conducted in three institutions in Malang, East Java, Indonesia. This research employed qualitatative approach with multisite study design. Data were collected by using interview, observation, and documentation. The analysis was done by using inductive analysis. Results of this research showed that these three institutions used a three-way strategies, which were (1) external strategy by creating identity with inovative and creative program, (2) internal strategy by developing quality services through educators character development, facilities fulfullment, educative media provision, and creation of conducive and pleasant learning environment, and (3) interactive strategy by developing mutual connection among schools, parents, an community, employing the use o connecting book, and easy payment.
\end{abstract}

Keywords: Strategy, Selling point, Early Childhood Education

\section{Citation:}

Wahyuni, Sri (2016); Strategies to enhance early childhood education institution selling point; Journal of Social Sciences (COES\&RJ-JSS), Vol.5, No.4, pp: 523-539. 


\section{Introduction}

One of the Millennium Development Goals (MDGs) target is the establishment of Education for All (EFA), which is education without descrimination and which must cover all ages including Early Childhood Education (ECD). UNESCO (2005) describes that the target of EFA on the ECD up to the year of 2015 has been $85 \%$ participation level of children aging 0-6 years. Such participation level also has been the long terms primary priority of the Southeast Asian Ministers of Education Organization (SEAMEO) program up to the year of 2035 (http://edukasi.kompas.com). These show that the ECD has been significantly gained attention and have important position in regional, national, and international levels. The Government of Indonesia Republic locates ECD as an important part of the National Education. Various efforts have been done by the governement considering the growth and development of early year children determine the pysical, mental, emotional, social, intelectual, learning ability, behavioral, and personality development (Nutbrown, 2006:62).

Since 200 the Indonesian Republic Government has managed to increase the ECD participation level to $72.6 \%$ in 2016 . In 2014, it was found out that the achievement was $69.4 \%$ (http://paud.kemdiknas.go.id). This indicates that $5.6 \%$ of the ECD in Indonesia have not gained ECD to match the EFA target of $75 \%$. The increase of the ECD participation levels has been clearly manifested by the increasing numbers of the ECD every year both those managed by the governmental institution and the private institutions. In 2013 there were 174.367 institutions comprising 74.487 Kindergartens, 70.477 Play Groups, 3.1354 Day Care, and 26.269 ECD equivalent or the so called lembaga satuan PAUD Sejenis (SPS) (Kemdikbud, 2013). However, There still are lots of problem in the quality of operation and services including the coverage of servicrs, types of services, children need services, and quality of the services (Kemdikbud, 2013).

To overcome such problems, the Indonesia Republic Government made the program priority in the National Education Development of 2010-2014. This has been put into the strategy to attain the golden generation 2045 as the outcomes of the ECD (Kompas.com, 2013). The Indonesian Republic Governement also launched integrative wholistic integrated ECD which covers 1000 PAUD. Each village must have one ECD to implement the Dakkar Convention in 2000 (http://kompas.com, 2013). This policy has implicated to the large numbers of new ECD established by the community managed by the Governement institutions, Private institutions, and Social as well as Religious institution.

East Java has been noted as having the highest level of participation reaching $76.39 \%$ (Kemdikbud, 2013), which means that the ECD services in this province has been very high. This evidence shows the existance of the competition among ECD institutions. One of the regions and municiples having high competitions of the ECD is Malang municiality. The development of ECD in this city has been satisfactory reaching the establishment of 572 institutions as follows: 
Strategies to enhance early childhood education institution....

Table 1 ECD INSTITUTION DATA IN MALANG

\begin{tabular}{|c|c|c|c|c|c|}
\hline $\begin{array}{l}\text { Organizing } \\
\text { Body }\end{array}$ & $\begin{array}{c}\text { TK/RA/BA } \\
\text { (Kindergarten) }\end{array}$ & $\begin{array}{c}\text { KB } \\
\text { (Play } \\
\text { Group) }\end{array}$ & $\begin{array}{c}\text { TPA } \\
\text { (Day Care) }\end{array}$ & $\begin{array}{c}\text { SPS } \\
\text { (Similar } \\
\text { ECD } \\
\text { Service) }\end{array}$ & Total \\
\hline $\begin{array}{l}\text { State/ } \\
\text { Govermental }\end{array}$ & 26 & 1 & 0 & 2 & 29 \\
\hline Private & 419 & 52 & 4 & 68 & 543 \\
\hline Numbers & 445 & 53 & 4 & 70 & 572 \\
\hline
\end{tabular}

(Source: http//referensi.data .kemdikbud.go.id)

The quantity development must be balanced with the quality development to make them acknowledged, chosen, and expected by the community and to enable them professionally compete with other institutions. The ECD Institutions have responsibilities to develop strtaegies of service quality enhancement continuously. An important thing to conduct for the success of the institutions is creating innovative education service ocialitation(Wijaya, 2012:2). The ECD institutions need to be proactive in providing best quality educational services to parents by employing propper strategies.

\section{Method of the research}

This research was aimed to understand the phenomenon of the strategy of the ECD Institution Selling Point among the three ECD institutions in Malang. The ultimate purpose has been to develop the substantive theory on the matter. Therefore, this research needed meaningul and thorough informarmation or data which could not only done by questionnairs. Therefore, this research employed the qualitative approach with multisite study design. The researcher took place as the main instrument and were present in edequate time in the research location to conduct indepht interview, diligent observation, documentation, and implement triangulation, make track record, and conduct member check to check the validity and reliability of the data. This research used inductive analysis technique comprising the within site and cross site analysis (Bogdan \& Biklen, 1998)

This research was conducted in three Integrated ECD Institutions in Malang, which are The Restu 2 Integrated ECD, As-Salam Integrated ECD, and Pelita Hati Integrated ECD. The informen was taken by using purposive sampling technique. The Principle of these three institutions were as key informen due to their important positions in their institutions. The researcher also involved educators, parents, administrators, and school committee. The followings are the informen.

Table 2. Informen List

\begin{tabular}{lllll}
\hline No & Informen & Restu 2 & As Salam & Pelita Hati \\
\hline 1. & Principals & 1 & 1 & 1 \\
2. & Educators & 3 & 2 & 3 \\
3. & Parents & 4 & 4 & 3 \\
4. & Administrators & 1 & 1 & 1 \\
5. & School Committee & 1 & 1 & 1 \\
\hline Total & & $\mathbf{1 0}$ & $\mathbf{9}$ & $\mathbf{9}$ \\
\hline
\end{tabular}




\section{Research Findings}

Based on the multi-sites analysis it was found out that there were three-way strategies to enhance the selling point of the ECD Institutions. What is meant by the selling point is strategic values of the ECD Institutions by which the institutions become acknowledged, expected, and chosen by the community as the trusted center of their children care. Strategies are meant as ways and efforts made by the ECD Institutions to enhance their service values. There have been three strategies employed by the three ECD Institutions comprising external, internal, and interactive strategies.

\subsection{External Strategies}

The ECD Institutions needed to develop brand identity to make them easy to recognize by the community. Each of the institution must have primary programs showing their uality characteristics. Such efforts turned out to appear in the external strategies as follows:

\subsubsection{Creating Institution Characteristics}

The Institutions characteristics have been very important to attract the community interest in their education services. Efforts to work on this made by Restu 2 was making the institution be the so-called Pesantren or Islamic Boarding School. The institution developed learning program focusing on the development of character and islamic values. The prioritized activities included memorization of daily prayers, short verses of $\mathrm{Al}$ Qur'an, and habituation of the prophetic behavior, and habituation of deeds and prayers. Every day children were trained to do Dhuha Shalat Morning Prayers and Dhuhur Prayers or Noon Prayers collectively together, and implementing islamic values such as giving every Friday, being truthful, learning to apologize, learning to thank. And learning to help. To support these, Restu 2 made school motto as "terbaik dalam iman, ilmu, dan akhlaq" (Best in dead, science, and morals).

As-Salam prioritizes on the formation of the moslem personality with noble characters and morals by focus in on the religious values and formation of the islamic morals based on the teaching of Prophet Muhammad SAW. The featured activities included memorization of the daily prayers, sort verses of Al Qur'an which is the so called juz amma, Names of Allah or the so called asmaul husna, and the so-called hadist arbain. For the memorization, this institution targetted children to memorize the first up to fouthieth names of Allah in semester one and the fourthy first to the ninty nineth names of Allah in semester 2, more than 30 daily prayers, and memorizing juz amma up to surah ad dhuha. The character development was done by focusing on the believe or Akidah and the life hystory of Prophet Muhammad or shirah nabawiyah. All activities were directed to the habituation of characters and morals both in mind and practices.

The characteristics developed by the Pelita Hati was the school concept on the basis of religion and environement. This Institutions prioritize not only the religious values, but also scientific environmental based learning. This institution developed a notion of utilizing environment for learning through gardening and outing classes. Children were trained to like vagetables by planting vegetables, and cooking vagetables. The school environemnt was designed nicely and greenfully to support the development of children characters in loving the environment. . 


\subsubsection{Creating Creative and Innovative Featured Program}

The Featured Program made by Restu 2 was making learning method change by modifying the BCCT (Beyond Center and Circle Time) to integrate the Reggio Emilia Method and Thematic Method. This implementation of this method was focused on the learning center forms. There were seven learning center forms developed including prparation, environment, creativity and arts, and blocks, deed and morals, audio visual, language, and role play. The other program innovation was in the form of the extra curriculair program including obigatory English day, computer, drumb band, morning kids story, and charity activity as well as the optional programs including drawign, coloring, singging, and the so-called tapak suci self-defense.

As Salam developed morning activities which was diferent from those done in the previous years? Every morning children were given opportunities to select our kinds of activities which included physical exercises, reading, reciting Qur'an, and making morning journal. This institution also showed the changes in managing the morning actvity system called "moving". In the morning activities children could meet different teachers and diferent friends. Ater completing the activities children received Great Stamp. As-Salam also modified and inovatted the BCCT learning method by having Moving System. Other innovative activites were "open house", managed in the "Charming Saturday" program comprising activities arrousing the children multiple intelligence and children characters through competitions, afirmation practices, and movement practices. As-Salam recruited "thaharah" teachers to help children do toilet training.

Innovations made by the Pelita Hati were organic biota (gardening), outing class, and 3R (reduce, reuse, and recycle) programs . Organic Biota learning was about learning organic plantation plantted in the limitted space, both vegetables and fruits. This program was designed to promote the interest and careness of children to the environment. Outing class was activities asking children to experience learning in the environment directly by utilizing resources surrounding the learning area based on the designed theme. $3 \mathrm{R}$ program was done by collecting and processing garbage. Every child was oblighted to throw garbage in the garbage appropriate garbage bin based on the chategories of wet, dry, paper, and can garbages. Pelita Hati also developed extracurriculair programs such as English class and Computer or Kids. In certain time, Pelita Hati conducted family day activity designed to involve parents.

The featured programs developed by these three institutions were diferent from other institutions which made the community be interested in sending their children to the selected these three institutions.

\subsection{Internal Strategies}

These strategies were made by providing educators having good characters and completing learning facilities. The three Institutions have made trmendous efforts o the ollowings:

\subsubsection{Providing Educators Having Good Characters}

The institutions conducted professional development regularly. The development concerned not only the learning and teaching skills, but also character. The character 
development bdecame prioritized activities in Restu 2 valuing educators as the most important people to transfer their character to children. Every educator had to own 4 main characters taught by the Prophet Muhammad, which were tabligh, shidiq, amanah, dan fathonah, as well as responsibility, caring, helping, and respecting one among others. The educators professional development in Restu 2 has been done since recruitment process in which every candidate was selected by having teaching, attitude, and Al Quran reciting tests. The institution also conducted routine and acidental activities such as daily reflection, weekly reflection, monthly reflection, training, preaching, and competitions. The Principal actively gave behavioral example and monitor the development of the educators characters. He used words and sentence affirmation such as . "Senyum itu Shodaqoh" (Smile is a deed), "Jadilah yang Terbaik" (Be the Best), "Bekerjalah dengan Ikhlas" (Work willingly) by hanging these on the wall for giving motivation to educators.

The character development became the important focus of As-Salam, eventhough all educators had been qualified and having university graduate diploma. Efforts made by the school to develop the educators character were (1) habituate the moto of "teaching by heart and examples, (2) provide religious gathering (liqo') and reflection once in every forthnight using topics of aqidah, ukhuwah, and akhlak tabligh, shidiq, amanah, fathonah, responsibilities, disciplines, trustworthy, caring, and togetherness, (3) lead by examples, guidance, and monitoring, (4) use afirmation words and sentences, aand (5) coordinate and collaborate with Matahati Foundation to educate character.

Pelita Hati also conducted routine character development for educators by oblighting every educator to own four characters exemplified by the Prophet Muhammad, which were shidiq, tabigh, amanah, and fathonah. The character development had been done since the first time educators were recruited and was continued by routine activities every month. In the meetings.

Performance evaluation was done to the educators. The educators were also given refreshment, training on the emotional intelligence, training educators to accept critiques and advise, and making accidental religious sessions, training, and competitions. To motivate educators, the principal put affirmative words or senteces in classes, such as words like "bekerja itu ibadah" (Work is a deed), "senyum itu shodaqoh" (Smile is giving), "Bekerjalah dengan ikhlas" (Work Wilingly), and "budayakan 3S (senyum, sapa, dan salam)" (Habituate $3 \mathrm{~S}$, Smile, Call, and greet). These words were put on the places which are easy to be seen by educators.

\subsubsection{Providing Approrpiate and Quality Facilities.}

The three ECD Institutions had made efforts to provide facilities including educative media, classrooms, and educative play toys. In the yard of the Restu 2 there were swing, sliding area, climbing area, small pool, water fountain which were arranged neatly for learning. Inside the classroom, there were indoor play area arrange neatly in every center area. Each of the center had its own room equiped with media and learning materials arranged neatly. To enhance the quality of educational services, the Insititutions had the principles of the numbers o facilities must be equivalent to the numbers of children. AsSalam and Pelita Hati also provided rooms devided into centers dequiped with complete facilities and media. Even, As-Salam provided sepcial playrooms for children. 


\subsection{Interactive Strategy}

The interactive strategies were developed by the three Institutions with the purpose of promoting mutual relationship aamong the institutions, parents, and community surrounding the schools. These srategies included (1) forming parents association and school committee involving in the school activities such as open house and outing class, (2) using connecting books, (3) using parenting program such as outing class and talkshow, (4) providing integrated services to help parents consult children problems. The integrated services included day care, play group, and kindergarten, and (5) making parents as media of promotion for the institutions. These strategies were categorized as follows:

3.3.1 Fulfilling The Need of Caring Through Integrated Services

Restu 2 developed three service programs managed by an intitution managed by one principal. These were Day Care, Play Group, and Kindergarten the so-called Bustanul Athfal (BA). With these three educational service programs, Restu 2 provided educational services to children aging 0-6 year for 06.30 a.m-17.00 p.m. These sevices were established due to the request of parents to have children learn and play in the whole day. These services were also meant to take care and educate children aging 0-6 years wholistically. Pelita Hati conducted Day Caree for children aging 0-6 years, play group for children aging 2-4 years, and Kindergarten or those aging 4-6 years. Pelita Hati made these services open due to providing parents expectation to have their children taken care in this institution up to the aternoon time. With these integrated services, the Institutions also gained high benefits, which were in every new academic year they did not to recruit new students which also made the cost administration effective.

\subsubsection{Providing Parenting Activities}

Lots of parenting activities were developed and conducted to promote relationship among schools, parents, and community surrounding the instituions. Restu 2 employed connecting books to communicate children development at schools to parents. Other ways to promote relationship was doing educative activities for parents through parents association activities. The parent association was initiated and established by parents and was named "Az Zahra". This parent association had routine monthly activities such as religious meetings, seminar, cooking class, parenting sessions, and final theme exhabition. Parents also were given opportunity to involve in classroom learning.

As-Salam made efort to unite all stake holders to establish school committee. Such initiation was made for the purpose of involving parents, community, and foundation aximize their roles in improving the schools. The institution always involved school committee in every school activity such as the final theme exhabition, open house, and other programs. The Institution also promote mutual relationship with mosque committee or the so-called takmir masjid and local community the so-called Rukun Tetangga (Neighborhood Group) and Rukun Warga (Collection of Neighborhood Groups), and other schools in the form of benchmarking such as learning to learn character development on the basis of the Prophet life history or the so-called shirah nabawi.

Parents were viewed as working partner and the means of the instituional promotion in Pelita Hati. The institution did not have to struggle for promotion when parents were actively help school to share educational information to other people targetting to be the propects of school parents. This institution used connecting book, educative seminar, 
parenting session, competition, talk show, cooking class, and provided integrated services. These services were provided to educate children wholistically.

The ultimate findings of this research could be illustrated as follow:

\begin{tabular}{|c|c|c|}
\hline $\begin{array}{l}\text { English } \\
\text { day, sabtu } \\
\text { ceria, } \\
\text { biota } \\
\text { organic, } \\
\text { family } \\
\text { day, } \\
\text { charity }\end{array}$ & $\begin{array}{ll}\text { Creating } & \\
\text { institutional } & \\
\text { characteri } & \text { Creating } \\
\text { using } & \text { Brand } \\
\text { featured } & \text { Identity } \\
\text { innovative } & \text { Identity } \\
\text { programs } & \\
\text { to easily } \\
\text { be }\end{array}$ & $\begin{array}{c}\text { Extern } \\
\text { al }\end{array}$ \\
\hline $\begin{array}{l}\text { - Selective } \\
\text { Recruitment } \\
\text { Process } \\
\text {-Religious } \\
\text { Sessions and } \\
\text { Training } \\
\text {-Words and } \\
\text { Sentences } \\
\text { Affirmation } \\
\text {-Educators } \\
\text { Performance } \\
\text {. }\end{array}$ & $\leftrightarrow \begin{array}{ll}\text { Good } \\
\text { character } \\
\text { educators and } \\
\text { appropriat } \\
\text { and quality } & \text { Insti } \\
\text { facilities } & \text { on-a } \\
& \text { Serv } \\
& \text { Qua }\end{array}$ & $\begin{array}{l}1 \\
\text { Strategi } \\
\text { tiga arah } \\
\text { (Three- } \\
\ldots \ldots . .\end{array}$ \\
\hline $\begin{array}{l}\text {-Three } \\
\text { integrated } \\
\text { Services } \\
\text { (Day Care, } \\
\text { Play Group, } \\
\text { and } \\
\text { Kindergarte } \\
\text { n) program } \\
\text { layanan } \\
\text { (TPA, KB, } \\
\text { TK) } \\
\text {-Parontino }\end{array}$ & $\begin{array}{l}\text { Fulfilling } \\
\text { parents need in } \\
\text { childreen care, } \\
\text { educational } \\
\text { activities, and } \\
\text { parents as } \\
\text { integrated part } \\
\text { of the school } \\
\text { promotion }\end{array}$ & $\begin{array}{l}\text { Promoting } \\
\text { mutual } \\
\text { relationsb: } \\
\text { p amor Interac- } \\
\text { parents tive } \\
\text { schools, } \\
\text { communit } \\
\text { y, and } \\
\text { fonndation }\end{array}$ \\
\hline
\end{tabular}


Figure 1. Selling Point Enhancement Strategies of the ECD Institutions.

\section{Discussion}

The ultimate findings of this research showed that the three ECD Institutions conducted various efforts as startegies to enhance their selling points as educational service institutions. The strategies were categorized into three groups, which were (1) conducted external strategy by developing their brand identities such as defining their institutions as character based schools and ennvironmental based school with their featured programs such as English day, charming Saturday, organic biota, family day, charity activity, and outing class; (2) conducted internal strategy by providing qualified educators with good characters, appropriate facilities, and other supports. For these instants, the institutions made various efforts of (a) developing educators character right since the recruitment process, (b) providing routine religious sessions and training for educators, (c) motivating educators by using words and sentences afirmation, (d) conducting suversion by the principals, (e) completing educative learning media, (f) and creating clean, green, and pleasant school environment and (3) employing interactive strategy by promoting mutual relationship among schools, parents, communities, and foundatons to meet parents need and expectation in children education and care as well as providing easy ways to serve parents in the process of the children development. In these instants, the institutions made various activities and programs such as (a) providing integrated educational services including Day Cares, Play Groups, and Kindergartens, (b) providing servise working time up to the afternoon, (c) providing parenting activities such as religious sessions, seminar, training, talkshow, or competitions, and (d) establishing school committee or parents association involving in school activities including final theme exhabition, open house, or outing class.

These srategies in the contet of the service management can be said as educational marketting strategies, which according to Kotler and Fox (1995) is said as activities of program analysis, planning, implementation, and controlling formulated carefully and designed for resulting educational service customer satisfaction. Zeithaml and Bitner (2003) state that educational service marketting is an activity to meet the need, expectation, as well as to meet the promise made by the education service institution for its customers. Such strategy is highly needed as a step to make the institution reamin having attention from the cmmunities of servise users and be in existance within the competitors.

Similar to Lockhart (2005) who views that educational markettin is highly needed due to the tight competition among educational institutions, Indradjaja and Karno (2007) suggests that education institutions need to reassure the community and service users that their offered education can be understood as fulilling the users expectation. Every institution makes eforts to provide unique, characterized, and featured learning programs such as having character development based learning and islamic values based intgernalized learning. Such featured identities were supported by activities of prayer memorization, Qur'an recitation, deed practices, noble and good morals habituation, and life skill development through extra curriculair programs. Such curriculum inclusion was made to create what is called in marketting as brand identities (Jasfar, 2009:224), which are trade marks showing instituional identities as a religious schools. Such uniqeness can make the institutions immage influence parents perceptions as the service users. 
The curriculum development with religious characteristics and character development inclusions need the roles of educators having good characters, too. Raealizing this premise, the insitutions provided educators continuous proessional development. The character development had been done right since the educators were recruited. Zeithaml and Bitner (2000) suggests that to build customer sutisfaction oriented educational services, schools are encuraged to conduct recruitment process by interviewing and selecting potential candidates. The three institutions turned out to do such program and afterwards the institutions conducted various activities such as refelctive sessions. Religious sessons, training, supervision by principals, and afirmation in order to enhance the educators' competence. Such strategy falls into the term internal strategy to demonstrate the educational service values through one-to-one relationship (Wijaya, 2012:20). The qualified and competent educators can demonstrate good performance that can meet the service users' satisfaction. Such strategy is in line with what is suggested by Michael G Fullan , as quoted by Suyanto (2000) as a strategy to attract parents interest by enhancing educators quality which can be linier with the quality of educational services. They can help children develop their interest, talent, ability, and potential. Students' interest, talent, ability, and potential cannot be grown without the helf of educators (Mulyasa, 2006:35).

Educators are a person giving care, love, exemplifier, and mentor for children (Lickona, 2012: 111). What they do certainly become the concerns of children and people surrounding them (Mulyasa, 2006:46). Therefore, professional development shall be conducted. Such program is meant to meet the competences required by the Government asd stated in the decree of the National education Ministry number 58, 2009. The early childhood learning educators must have minimum qualification of the diploma IV or graduate diploma specialing in the early childhood education or at least they have early child education training.

The Institutions contnuously made changes by developing creative and innovative programs in enhancing the children characters and potentials. Such innovative program is needed to make changes and to ensure the service user satisfaction. Such programs are called differentiation strategy (Michael Porter, in Jasfar, 2009:104). The strategy prioritize the existance of unique and different services compared to those same type services. This strategy is also called educational innovation to make the educational service products different from their competitors (Wijaya, 2012:69). The schools provided programs as the manifestation of this strategy in the orms of morning journal, charming Saturday, gardenning or organic biota, outing class, and affirmation. Kazmi (2007) says that dfferentiation strategy is a process to create different offering and to differentiate the organiation from others by using a numbers of tools so that there are meaningful added values to the organiation offers.

Other efforts to attract service users were providing appropriate and complete facilities and arranging the schools environment to be green and clean. The Institutions also provided adequate rooms, indoor, as well as outdoors learning media and equipments. Each of the centers also were completed with complete learning play tools. These efforts were made to establish good immages of the Institutions to the service users. The provision of the facilities can help the good phisical performance of the Institutions and can be the attraction of the parents. According to Parasuraman such phisical appearance enables them to form the first immage and create the service user trust (Wijaya, 
2012:225). Zeithaml and Bitner view these as the package of the Institutions and the differentiators of the Institutions to other Institutions.

The success of the educational institutions relates to the roles of parents and surrounding communities. Parents and the surrounding communities as external service users have high influences to determine the continuation of the Institutions. These people are the best marketting agent who are able to give the Institutions feed back and concerns through words of mouth communication. What parents feel about the institutions can be captured by the surrounding community (Wijaya, 2012: 20). Considering these conditions, the Institutions promoted mutual harmonic relationship among the schools, parents, and communities surrounding the schools as the interactive strategy to create service user satisfaction (Wijaya, 2012:21). Such efforts included the parents association and school committee, routine religious sessions, training, parenting education, and competitions. Such efforts are called by Michael G Fullan, in Suyanto (2000) as optimizing parents and students potentials to enhance the community participation in schools activities. Each of the Early Chilhood Institution needs to make relationship based on the partnership collaboration and mutual trust (Stokes, 1996). These relationships shall happen both within and outsite of the Institutions. Gronroos (1984) says that the relationship among service users, employees, and interaction processes can formulate service triangle marketting.

The three integrated educational service model comprising the Day Cares, Play Groups, and Kindergartens turned out to aim at providing wholistic educational care and learning to children which were not only intended on the cognitive development. Such program is inline with the Early Childhood Education (ECE) program developed in the United States of America (Brown, 2011:8). Such educational services will ease parents who have high mobilities and works to have their children safe. Cochran says that the existance of such institutions can provide opportunities to women who involve in job markets and to have their children safely taken care (Brown, 2011:7).

In summary, the three ECE institutions developed startegies to create brand identities, building parents and community trusts, making parents peace of mind, and providing easy children care to parents. Such efforts are the forms of educational marketting strategy. Kotler (1992:126) says that such eforts can enhance the quality of performance and services. Moreover, the eorts would be more beneficial to have the Institutions selective in recruitin educator candidates, provide additonal meaningul services, providing useful acilities, and providing additional content of learning. Nurhadi (2005) says that such strategy can be called as a promotion to provide service user satisaction services. These can be done effectively in order that the service users can be interested in sending their children to the schools. These also are done in order that students, parents, school employees, and communities trust the schools Lockhart (2005).

\section{Conclusions}

The strtaegies to enhance the ECE Institution Selling points turned out to be the three way strategy comprising External, Internal, and Interactive Strategies. The external strategies concerned with the creation of brand identities of the Institutions by developing creative and innovative programs in order that the community could easily akcnowledge and trust the institutions. The Internal strategy concerned developing the quality of educational services through continuous profesional development of the educsators 
including the character development, complete and appropriate facilities provision, and conducive school environment creation so that children were pleasant in learning and parents tust the schools. The interactive strategy concerned promoting mutual relationship among schools, parents, communities, and foundations through the three integrated educational service programs comprising the Day Cares, Play Groups, and Kindrergaten, connecting books, parenting activities, easy cost payment services, and fulfilment of the parents expectations.

\section{References}

Alex. Service Marketing and Non Profit Marketing. http://www.udel.edu/ alex/chapt 24.html.

Diakses 25 Juni 2014. (2006)

Alma, B. Manajemen Pemasaran dan Pemasaran Jasa. Bandung: Alfabeta. (2004)

Anwar, K. Manajemen Pemasaran Sekolah sebagai Salah Satu Kunci Keberhasilan

Persaingan $\backslash$

Sekolah. (online). Diakses 12 Juni 2015. (2008)

Arifin, I. Kepemimpinan HIMPAUDI: Studi Kasus di Kota Malang. Malang: Aditya

Media $\backslash$

Publishing. (2011)

Ary, D., Jacobs, L. C., \& Razavieh, A. Introduction to Research in Education. Sixth Ed.

Belmont, CA: Wadsworth, Thomson Learning. (2002)

Asmawati, L. Pengelolaan Kegiatan Pengembangan Anak Usia Dini. Jakarta:

Penerbit

Universitas Terbuka. (2008)

Babbie, E. The Basic of Social Research. Fourth Ed. Belmont, CA, USA: Thomson

Wadsworth. (2008)

Bennis, W. On Becoming a Leader. London: Hutchinson. (1989)

Bernard, C. I. The Function of The Executive. Cambridge, Mass: Harvard University

Press.

(1988)

Bitner, M.J., R.P. Fisk., \& S.W. Brown. Tracking the Evolution of the Services Marketing

Literature. Journal of Retailing. Vol.69, hlm.13-60. (1993)

Bogdan, R.C., \& Biklen, S.K. Qualitative Research for Education: An Introduction to

Theory and Methods. Boston: Allyn and Bacon. (1998)

Boardman, M. Changing times: Changing Challeges for Early Childhood Leaders.

Australian

Journal of Early Childhood. Vol. 28. No.2. pp. 5-20. (2003)

Brock, A. Building a Model of Early Years Professionalism from Practitioners

Perspectives. 27

Nopember 2013 published online by Journal of Early Childhood Research: SAGE

Publications.

Brown, C., Lisa, A., \& John, W. 2011. Introduction: Crossiy Boendaries and

CollidingWorld:

The Polities of Prekindergarten Education. Journal Educational Policy. Vol. 25. No. 1. pp. 3-8

Caldwell, B.J., \& Spinks, J.M. 1993. Leading the Self Managing School. London: The

Falmer

Press. 
Caldwell, B. Foreword, Early Childhood Professionals. Leading Today and Tomorrow.

Sidney:

Maclennan and Petty Pty Ltd.(2003)

Cartwright, D., \& Zander, A. Group Dynamics: Research ang Theory. Evanston: Row and

Peterson. (1953)

Cohen, L., \& Manion, L. Research Methods in Education. Third Edition. London:

Routledge. (1989)

Creswell, J. W. Research Design: Qualitative \& Quantitative Approaches.

Thousand Oaks, CA: Sage Publications, Inc. (1994)

Creswell, J. W. Research Design: Qualitative, Quantitative, and Mixed Methods

Approaches.

Third Edition. Thousand Oaks, CA: Sage Publications, Inc. (2009)

Ebbeck, M., \& Waniganayake, M. Early Childhood Professionals: Leading Today and

Tomorrow. Sidney: McLennan \& Petty Pty Ltd. (2003)

Etzioni, A. A Cooperative Analysis of Complex Organizations. New York: Free Press. (1964)

Faisal, S. Penelitian Kualitatif: Dasar-dasar dan Aplikasinya. Malang: YA3. (1990)

Faisal, S. 2006. Analisa Data dalam Penelitian Kualitatif. Makalah disampaikan pada pelatihan

Penguatan Penelitian bagi Dosen Universitas Widyagama Malang. LPPM

UniversitasWidya Gama Malang. 3 Oktober 2006.

Fitzsimmons, Mona J.F Service Management: Operation, Strategy and Information

Technologi.

Mc.Graw Hill. New York. (2001)

Foskett, N.H. Managing External Relations in Schools: A Practical Guide. London:

Routledge

Falmer. (1992)

Fullan, M. The New Meaning of Educational Change. New York: Teachers College Press. (1991)

Geoghegan, N., Petriwskyj, A. Bower, L., \& Geoghegan, D. Eliciting Dimensions of Educational

Leadership in Early Childhood Education. Australian Research in Early Childhood Education.

Vol.10. No.1. pp 12-23. (2003)

Glaser, B., \& Strauss, A. 1980. The Discovery of Grounded Theory: Strategies for

Qualitative

Research. New York: Aldine Publishing Company. (1980)

Gronroos, C. A Service Quality Model and Its Marketing Implications. European Journal of Marketing. Vol. 18. No. 4. pp. 36-44. (1984)

Harini, S. Mendidik Anak Sejak Dini. Yogyakarta: Kreasi Wacana. (2003)

Haryanto, R \& Sylvia, R. 2012. Pengembangan Strategi Pemasaran dan Manajemen Humas

dalam Meningkatkan Peminat Layanan Pendidikan. Jurnal Ekonomi dan Bisnis Volume 11

Nomor 1, Juni 2012: 27-34

Hasan, M. Pendidikan Anak Usia Dini (PAUD). Diva Press. Yogyakarta. (2009) 
Hoy, W.K., \& Miskel, C.G. Educational Administration: Theory, Research, and Practice. Boston: McGraw-Hill.(2001)

Hunger, J. D., Thomas, I., \& Wheelen. Essentials of Strategic Management. Boston:

Pearson.(2011)

Hunsaker, P.L.Training in Management Skill. Uppers Sadle River New Jersey: Prentice Hall. (2002)

Indradjaja, T., \& Karno, B.P.. Bahan Seminar Pemasaran Sekolah. Semarang: Program Pasca

Sarjana Magister Manajemen Konsentrasi Manajemen Sekolah. (2007)

Irawan, H., \& Juwandi. Kepuasan Pelayanan Jasa. Jakarta: Erlangga. (2004)

James, A., \& Andrian, L.J. Studies in Childhood and Youth. England: Macmillan Distribution. Ltd. (2012)

Janet, G., \& Diane, W. Infant, Toddler, and Caregivers. London: Delmars Publishers. (2001)

Jasfar, F. Manajemen Jasa: Pendekatan Terpadu. Bogor: Ghalia Indonesia. (2009)

Jatmiko, R.. Manajemen Strategik. Malang: UMM Press. (2003)

Johnson, B., \& Christensen, L. Educational Research: Quantitative, Qualitative, and Mixed

Approaches. Second Edition. Boston: Pearson. (2009)

Kazmi, S.H.H. Marketing Management. New Delhi: Bharathiar University. (2007)

Kemdikbud, 2013. Rencana Strategis Pendidikan (http://www. kemdikbud.go.org)

Kompas.com. 2013. Jumlah PAUD Terpadu Akan Dilipatgandakan. (http:/

kompas.com.

diakses tgl 9 Oktober 2013).

Kompas.com. 2015. Anis Baswedan Bakal Pimpin Organisasi Menteri Pendidikan Asia

Tenggara.

(http//edukasi.kompas.com, diakses 13 November 2015).

Kotler, P. Manajemen Pemasaran Analisis, Perencanaan, dan Pengendalian Jilid 2.

Terjemahan

Herujati Purwoko dan Jaka Wasana. Jakarta: Erlangga. (1992)

Kotler, P., \& K.F.A.Fox. Strategic Marketing for Educational Institution: Englewood Cliffs. New

Jersey: Prentice Hall. (1995)

Kotler, P. Manajemen Pemasaran Jasa: Teori dan Praktek. Alih bahasa Hendra Teguh, Roni A.

Rusli. Jakarta: Prehallindo. (2006)

Kotter, J. 1989. What Leaders Really Do. Harvard Business Review. Vol 67. No 3, pp. 103-11.

Khoiriyah, M. 2008. Manajemen Strategis Peningkatan Mutu Pendidik: Studi multikasus pada

MAN Tlogo Blitar, SMAN I Blitar. Tesis tidak diterbitkan. Malang: PPS UIN.

Law, S., \& Glover, D. Educational Leadership and Learning. Practice, Policy and

Research. Open

University Press. Buckingham. (2000)

Lickona, T. Educating for Character: Mendidik untuk Membangun Karakter

Diterjemahkan oleh

Juma Abdu Wamaungo. Bandung: Remaja Rosdakarya. (2013) 


\section{Strategies to enhance early childhood education institution....}

Lincoln, Y., \& Guba, E.G. Naturalistic Inquiry. Beverly Hills: Sage Publications. (1985)

Lockhart, J.M. How to Market Your School: A Guide to Marketing, Public Relations, and Communication for SchoolAdministrator. Iuniverse. Inc. (2005)

Looy, Bart Van, Roland Van Dierdonk, Paul Gemmel. Service Management: An

Integrated Approach.

London: Financial Times Pitman Publishing. (1998)

Lupiyoadi, R., \& Hamdani, A. Manajemen Pemasaran Jasa. Jakarta: Salemba Empat. (2008)

Mantja, W. Etnografi: Desain Penelitian Kualitatif Pendidikan dan

Manajemen Pendidikan. Malang: Elang Mas. (2008)

Margaretha, Y. 2011. Analisis Pengaruh Bauran Jasa Terhadap Minat Beli pada Program Magister

Manajemen Universitas Kristen Maranatha. Jurnal Semantik. ISBN 979.26.0255.0

Marshall, C., \& Rossman, G. Designing Qualitative Research. USA: SAGE Publications. (1989)

Mawson, W.B.. Children's Issues Laws and Program: Collaborative Play in

Early Childhood Education. New York: Nova Science Publishers, Inc. (2010)

Melhuish, E., \& Petrogiannis, K. Early Childhood Care and Education: International

Perspektives.

USA: Routledge. (2006)

Mihaela, S. 2011. Program Pengembangan Organisasi di Lembaga Pendidikan Pra Sekolah (An Organizational Development Program in The Preschool Educational Institution).

(online). (www.sciencedirect.com). Diakses 20 September 2013

Miles, M.B., \& Huberman, A.M. Analisa Data Kualitatif. Terjemahan Tjetjep

Rohendi

Rohidi. Jakarta: UI Press.(1992)

Moedzakir, M.D. 2010. Desain dan Model Penelitian Kualitatif : Biografi, Fenomenologi, Teori

Grounded, Etnografi, dan Studi Kasus. Saduran dari buku Qualitative Inquiry and

Research

Design: Choosing Among Five Traditions, oleh Prof. John W. Creswell, copyright 1998, diterbitkan oleh Sage Publications, Inc, Malang: Fakultas Ilmu Pendidikan Universitas Negeri

Malang

M.N. Nasution. Manajemen Mutu Terpadu. Jakarta: Ghalia Indonesia. (2000)

Moyles, J. The Role of Play in the Foundation Stage. Foundation Stage Conference.

Cornwall

Educational Development Service. Newquay. Cornwall. (2003)

Mulyasa, L. Menjadi Guru Profesional: Menciptakan Pembelajaran Kreatif dan

Menyenangkan. Bandung: Remaja Rosdakarya. (2006)

Murden, T.. Principles of Strategic Management. USA: Asghate Oxford,Learner's Pocket Dictionary.2005.Newyork, Oxford University Press. (2007)

Neugebauer, R. 1985. Are you an Effective Leader?. Child Care Information Exchange.

Vol. 46.

pp18-26

Nurhadi. 2005. Pentingnya Promosi dan Kualitas Layanan Terhadap Kelangsungan Hidup Lembaga Penjual Jasa. Jurnal Ilmu Manajemen Volume 2 Nomor 1 Tahun 2005 
Nutbrown, C. Key Concepts in Early Childhood Education and Care. London: SAGE Publication Ttd. (2006)

Parasuraman, A. Valene, A. Zeithamli, Leonard, L. Berry. 1985. Journal of Marketing. A Conceptual Model of Service Quality and Its Implication for Future Research.

Patton, M. Q. Qualitative Research and Evaluation Methodes. Third Edition.Thousand Oaks,

CA: Sage Publications, Inc. (2002)

Permendiknas RI Nomor 13 Tahun 2007 tentang Standar Kepala Sekolah. Jakarta Permendikbud RI Nomor 137 Tahun 2014 tentang Standar Nasional Pendidikan Anak Usia Dini. Jakarta

Permendikbud RI Nomor 146 Tahun 2014 tentang Kurikulum 2013 Pendidikan Anak Usia Dini.Jakarta

Permendikbud RI Nomor 84 Tahun 2014 tentang Pendirian Satuan Pendidikan Anak Usia Dini. Jakarta

Peraturan Presiden Nomor 60 Tahun 2013 tentang Pengembangan Anak Usia Dini Holistik Integratif. Jakarta

Prayitno,I. Kepribadian Muslim: Panduan Bagi Da'I dan Murabbi. Jakarta: Tarbiatuna. (2003)

Rood, J. Kepemimpinan PAUD. Terjemahan Imron Arifin. Yogyakarta: Aditya Media. (2010)

Santrock, J.W. A Tropical Approuch to Life-Span Development Perkembangan Masa

Hidup. Boston, Mc. Graw Hill. (2002)

Santrock, J. W. Perkembangan Anak. Boston: Mc. Graw Hill. (2007)

Soetopo, H. Kepemimpinan Pendidikan. Malang: Fakultas Ilmu Pendidikan Universitas Negeri Malang. (2010)

Spradley, J. Participant Observation. New York: Rinehart \& Winston. (1980)

Stake, R.E. Qualitative Research: Studying How Things Work. New York: The Guilford Press. (2010)

Stokes, D.. Relationship Marketing in Primary Schools. Proceedings of the Market in Education Policy, Process and Practice. Symposium: University of Southampton. (1996)

Suharsimi, A.. Prosedur Penelitian. Jakarta: Rineka Cipta. (1993)

Sugiyono. Metode Penelitian Kuantitatif dan Kualitatif dan R\&D. Bandung: Alfabeta. (2010)

Sujiono, Yuliani, N.. Konsep Dasar Pendidikan Anak Usia Dini. Jakarta: PT Indeks. (2009)

Tadepalli, R., \& T. Hayes. The Ten Do's and Don'ts of Marketing Strategy. Baltimore: American Marketing Association Symposium on Marketing Higher Education. (2000) Tjiptono, F., \& Anastasia D., Total Quality Management. Yogyakarta: Andi Offset. (2003) Undang-undang Republik Indonesia Nomor 20 Tahun 2003 tentang Sistem Pendidikan Nasional. Jakarta

UNESCO. 2005. Policy Review Report: Early Childhood Care and Education in Indonesia.

Early Childhood and Family Policy Series, No. 10.

Wijaya, D. Pemasaran Jasa Pendidikan: Mengapa Sekolah Memerlukan

Marketing?. Jakarta: Salemba Empat. (2012)

Yin, R.K. Qualitative Research From Start to Finish. New York: The Guilford Press. (2011)

Zeithaml, V.A., M.J. Bitner. Service Marketing. New Jersey:McGraw-Hill. (2003) 
Strategies to enhance early childhood education institution....

Zembata, R. 2010. The Relationship Between the Effectiveness of Presschools and Leadership

Styles of School Managers. Artikel diterbitkan oleh Procedia Social and Behavioral Science.

ISSN 1877-0428. Vol. 15. pp. 998-1002 